\title{
The Impact of COVID-19 on the Work of Property Valuers: A Glance at the Polish State of Play
}

\author{
Małgorzata Uhruska and Agnieszka Małkowska *(D) \\ Department of Real Estate and Investment Economics, Cracow University of Economics, Rakowicka 27, \\ 31-510 Cracow, Poland; uhruskam@uek.krakow.pl \\ * Correspondence: malkowsa@uek.krakow.pl; Tel.: +48-12-293-5593
}

Citation: Uhruska, Małgorzata, and Agnieszka Małkowska. 2021. The Impact of COVID-19 on the Work of Property Valuers: A Glance at the Polish State of Play. Journal of Risk and Financial Management 14: 378. https://doi.org/10.3390/ jrfm14080378

Academic Editor: Kim Hiang Liow

Received: 20 July 2021

Accepted: 12 August 2021

Published: 16 August 2021

Publisher's Note: MDPI stays neutral with regard to jurisdictional claims in published maps and institutional affiliations.

Copyright: (c) 2021 by the authors. Licensee MDPI, Basel, Switzerland. This article is an open access article distributed under the terms and conditions of the Creative Commons Attribution (CC BY) license (https:// creativecommons.org/licenses/by/ $4.0 /)$.

\begin{abstract}
This article presents how the COVID-19 pandemic affected the valuation profession in Poland in the early stages of its most severe restrictions and limitations. This study is the first to investigate the impact of COVID-19 on the professional activities of property valuers. In particular, it aims to identify the difficulties associated with valuers' activities during the first lockdown and the impact of restrictions on business performance. The data analyzed come from a survey of Polish valuers in September 2020. The questions were of a closed-ended nature. Using a five-point Likert scale, respondents expressed their opinions on the difficulties and benefits of their work in the first COVID-19 period. The results show that the respondents experienced difficulties related to the pandemic and noted its negative impact on business performance. The most significant problem was the limited access to public institutions supporting the valuation process and providing market data on real estate transactions. The respondents also indicated other problems related to property valuation, as well as some positive effects for their business.
\end{abstract}

Keywords: property valuer; property valuation; COVID-19 pandemic; COVID-19 impact; property valuation business; real estate services

\section{Introduction}

The COVID-19 pandemic has affected everyone-workers, entrepreneurs, corporations, and public institutions-in an unprecedented way. However, the severity and manner of impact have been multi-directional. For some industries, the lockdown period proved devastating, but for others, the new reality brought new growth prospects and sources of income (Abay et al. 2020; Slade 2020; Sokol and Pataccini 2020). However, regardless of geography, industry, position, or occupation, most employers and employees have faced unexpected circumstances, traumas, uncertainties, and constraints. It has prompted many companies, including SMEs, to rethink and reformulate their business models, primarily toward greater reliance on digital technologies (Priyono et al. 2020; Abed 2021) and the implementation of new forms of work delivery (Savić 2020).

It is clear that the negative impact of pandemic-related constraints varied in depth depending on, but not limited to, the industry (He et al. 2020), the structure and size of the firm (Fabeil et al. 2020; Tkach and Kurpayanidi 2020), the type of products and services produced, and the possible distribution channels (Seetharaman 2020). Services, especially those in the information industry, where the ability to work remotely did not face significant barriers, suffered less than those where face-to-face contact with the customer was crucial (Fairlie and Fossen 2021; Hasanat et al. 2020; Sheth 2020; Shen et al. 2020). On the other hand, for the continuity of orders in business service industries, the core industries for which certain information services are provided are essential. Therefore, the health of supporting services also depends on the degree of freezing of the primary branches.

This study focuses on the rather specific industry of real estate valuation and the professional activities of Polish valuers in the first period of the COVID-19 pandemic. 
Property valuation services are information-oriented, and expertise is an essential resource in this business. Although there are low fixed costs in the real estate valuation business, and the nature of this profession means that the vast majority of valuation companies are sole traders with no permanent employees, the recommendations of social distancing and the lockdown of the economy have hindered the proper provision of these services. Therefore, in our study, we want to find out to what extent the situation triggered by the COVID-19 pandemic has affected the professional practice of valuers. The direct objective of our research is to identify the difficulties associated with carrying out the core tasks of determining property values. We also want to know how valuers perceived the situation in which they had been placed. Has it had an impact on their business performance? In order to address these research questions, we conducted an online survey in September 2020 among Polish property valuers affiliated with professional associations across the country. The range of questions that was asked to the respondents concerned the most relevant problems that they had to face during the pandemic. The time frame of the survey covered the first lockdown from March 2020.

As it might seem that property valuation is a business like any other, it should be pointed out that in Poland, property valuation is a regulated profession. It is a wellrespected profession of public trust which can be practiced only by persons with state professional qualifications. The uniqueness of the profession can be attributed not only to the limited scope of entry into the profession, but also to the fact that it is set in a rigid framework of existing legal regulations. The practice of valuation is widely governed by legislation covering valuation methodology, the principles of valuation in the context of specific valuation purposes, the scope of the market data used, and even the rules of professional education and professional liability (Real Estate Management Act 1997; Regulation on Real Estate Valuation and Making a Valuation Report 2004). The existing organizational and legal conditions of the profession set out in detail the rules for the professional activity of Polish valuers, but they also set clear boundaries for the business independence of valuers (Kucharska-Stasiak 2009; Źróbek and Grzesik 2013; Konowalczuk 2017). These boundaries may pose impediments to professional activity in the face of the crisis situation faced by professional actors at the onset of the COVID-19 pandemic.

The valuer, in order to carry out the valuation in a proper and compliant manner, is required to perform certain professional activities (e.g., carrying out a site inspection of the property) and to base the valuation on up-to-date market information (verification of price data and transaction terms in the notarial deed). Restrictions introduced during the pandemic such as the freezing of public institutions that collect and provide information about the real estate market, and the lack of prepared solutions for the time of crisis with the limited use of digital technologies in companies and public institutions raise the question about the possibility of conducting professional activities in accordance with legal requirements and are a factor that prompted the present research problem. To date, no research has been encountered on the impact of the pandemic on the activities of real estate valuers. Any existing studies in general describe the professional activity in the pandemic real estate market (Koszel 2021; Majumder and Biswas 2021) or refer to other professions (Marona and Tomal 2020; Gross 2021). The present research on the functioning of Polish real estate valuers will complement the picture of the impact of the pandemic on the activities of real estate professionals, and it may be a thread in the discussion of whether the rigid professional framework supports their representatives in the face of external difficulties. It will also provide an insight into how valuers are coping in a rather peculiar Polish real estate market which, on the one hand, is booming, and on the other, it is facing problems such as imperfect access to information on market transactions, imperfect public property registers, and low levels of digitization and use of ICT innovations by both business and public institutions before 2020 .

This paper is structured as follows. Section 1 provides an overview of the impact of the COVID-19 pandemic on the property market and the valuation profession, Section 2 
covers the characteristics of the data and method used, Section 3 contains the research findings and discussion, and Section 4 provides the conclusions.

\section{Property Valuation Services in Poland during the COVID-19 Pandemic}

To meet the research objectives, in this section, we take a closer look at the special conditions of the real estate market during the COVID-19 pandemic as a backdrop to the activities of real estate valuers who take on professional challenges under these unusual circumstances.

\subsection{Real Estate Market in a New Pandemic Reality}

The impact of the pandemic on the functioning of the real estate market is undeniable. Of course, it is all in the details. In order to describe the impact of the pandemic on the real estate market, one would have to assess its individual sectors. However, in the context of this article, we will omit detailed characteristics of the changes that took place as a result of pandemic restrictions and only hint at certain elements of the new market reality and to what extent they may have affected the activities of real estate valuers.

The greatest influence on the functioning of the market is the structure and the relationships of the entities operating in it. The basic groups of real estate market entities include real estate users (owners and tenants), investors, financial service providers, as well as entities and institutions supporting the real estate transaction. All these groups of entities practically halted their activity in the first few months of the pandemic, limiting their activities to the minimum. In the first full lockdown lasting from mid-March to the end of April 2020, practically all sectors were closed down. On the real estate market, all planned transactions were postponed, the ongoing investments were put on hold, notary offices were closed, and public offices functioned only on an emergency basis. Eventually, in May 2020, successive phases of easing restrictions allowed for a gradual thawing of the hibernated real estate market reality (Coronavirus: Information and Recommendations 2020). The real estate industry quickly came back to life; however, the consequences of the pandemic were still felt in the form of limited activity of market players due to the changing restrictions and high uncertainty regarding the future.

It is the activity of market players, their actions aimed at executing property lease or sale contracts, the necessity of financing and securing these transactions, or finally, the administrative and tax obligations of market players that make it necessary to estimate the value of real estate, and property valuation services become an indispensable element in the real estate market mechanism. Therefore, it can be concluded that as a result of reduced activity of the market players, the demand for property valuation services will automatically decrease. The question that can be posed is whether the difficult situation in which investors found themselves in the first period of the pandemic did not paradoxically contribute to an increase in the number of valuers' orders. How did empty office buildings, closed shopping malls, and reduced sales in real estate affect the professional activity of valuers?

From the very beginning of lockdown, constraints on the operation of commercial buildings, mainly office and retail (Freeman 2020), as well as constraints on the sale and rental of housing (Marona and Tomal 2020; Yoruk 2020) were evident. Observing the changes that have taken place in the commercial real estate market and the housing market will certainly have consequences in the long term. The COVID-19 pandemic has definitely accelerated certain trends in the real estate market. Physical office space has moved into the virtual world, and the variant of remote working, or at least rotational working (Ipsen et al. 2021), will be used to create work arrangements in the future. The shift of traditional commerce into the e-commerce zone (Nanda et al. 2021) has led to an increase in the importance of warehouse facilities and logistics centers, which have taken over the entire sales and customer service process in a short period of time. This shift was detrimental to traditional stores. Physical stores were faced with a change in operating strategy in terms of forms of sales and customer service. The consequences 
of such actions, although postponed to a later time, will be very wide. Investors in the commercial market will face the necessity of rearranging the lease space and experience the problem of increasing vacancies, lowering rental rates, and decreasing operating income, thus reducing the effectiveness of the investments made and decreasing the reliability of financial security (Voigtländer 2020; Parker 2020).

Changes have also occurred in the area of the residential market, both in terms of renting and selling properties. Owners of rental housing (long term being typical of student rentals and short term being typical of tourist cities) have faced similar problems to retail and office buildings (Marona and Tomal 2020). Reduced demand has reduced owners' incomes, leaving them with unchanging facility maintenance costs and mortgage obligations, increasing the risk of the investments they have made. On the other hand, in the area of real estate sales, there was a reduction in the volume of apartments sold, which was mainly due to investor uncertainty as well as the tightening of bank criteria for mortgage loans.

Undoubtedly, restrictions related to the COVID-19 pandemic forced changes in the attitudes of market participants and created new solutions for the functioning of the real estate market. Many investors, entrepreneurs, and private property owners have faced difficult financial situations and important related decisions. These decisions will require a variety of actions, both in the short and long term. The role of valuers can be expected to be significant in supporting the decision-making process of market participants, renegotiating loan terms, and assisting in the resolution of property conflicts and mutual claims, whether through mediation or litigation. However, the answer to the question posed earlier as to whether the pandemic will increase the activity of real estate appraisers is not so obvious. A so-called delayed reaction can be expected here. Demand for property valuation services may increase, but not immediately. Providing property valuations will be necessary for evidentiary purposes in pending loan, business, and court proceedings, which are more likely to be initiated at a later date (i.e., when the pandemic situation is more stable). In the short term, on the other hand, it can be expected that a pandemic is unlikely to provide property valuers with a greater volume of valuation orders. Furthermore, in the face of a pandemic, valuers will experience similar difficulties and constraints to other parallel market players.

\subsection{Pandemic Challenges for Polish Property Valuers}

The property valuer plays an important economic role in the real estate market by providing information about the value of the property (Bartke and Schwarze 2015). Valuation involves the objective assessment of key property characteristics in the context of local real estate market conditions. Any expert valuation should be objective and justified based on objective market data. Independent and unbiased valuation informs the parties of the transaction of the actual potential value of the property and the possible investment risk, eliminating the problem of asymmetric information and a lack of transparency in the real estate market and thereby reducing transaction costs, shortening the negotiations, and speeding up the implementation of the transaction.

Property valuers, in functioning as trusted experts in the market place, must maintain the highest professional and ethical standards in accordance with recognized professional requirements (e.g., National Valuation Standards 2021 and International Valuation Standards 2020) which are designed to ensure consistency of valuation practices internationally, increase the transparency of reports, build confidence in property valuation instrumentally as well as institutionally, ensure quality service, and support the development of the valuation profession. In addition to these general principles of the best practices in property valuation, each country may have specific legal regulations interfering with the practice of the profession.

Poland is a country where property valuation is firmly rooted in legislation which regulates the principles of property valuation in great detail, ranging from the rules governing the awarding of professional qualifications to valuation methodology, the principles 
of continuing education, the scope of professional responsibility, and even the conduct of business in this field. The specifics of property valuation in Poland are outlined below, mainly in the context of the profession's vulnerability to pandemic conditions and associated restrictions.

The valuation profession in Poland is relatively young, having formally come into being at the beginning of 1998 in response to market needs arising from the ongoing transformation of the political system. Prior to that time, valuation of real estate was carried out by various specialists such as surveyors and cost estimators. However, in the late 1990s, valuation rules were clarified, a detailed valuation methodology was developed, and the profession was formally established. Property valuation in Poland is a regulated profession which can only be entered by individuals with appropriate preparation. In Poland, only persons holding a professional qualification confirmed by a state license are allowed to work as valuers. To obtain such a qualification, one must complete appropriate courses or theoretical studies and enter a professional practice, after which one must pass a state examination.

The impact of the pandemic can already be seen in this area. Significantly fewer professional certificates have been granted in 2020. According to data from the Ministry Economic Development Labour and Technology (Central Register of Property Valuers 2021), a total of 7794 professional licenses were issued between 1998 and 2020. Their annual growth varied from one period to another, with an average of 283 new valuers each year in the last 5 years preceding the pandemic (i.e., 2015-2019). During the pandemic period, there was a marked decline in this number, and so in 2020, only 95 people were licensed. Such a clear decrease in the number of new real estate valuers is mainly due to the reduction in the number of people taking the exam as a result of not just the reduction in the number of examination proceedings (from six to three per year), but also the individual reasons of the candidates (e.g., health condition, isolation, or quarantine) (Cymerman 2021). By way of comparison, in 2019, nearly 649 people took the first stage of the exam, and 1 year later, there were only 262 candidates taking the exam. Reductions in the number of applicants to the profession may also result from restrictions on postgraduate education. Not all existing academic institutions launched valuation studies during the pandemic.

The changes caused by the COVID-19 pandemic not only resulted in fewer people entering the profession but also may have affected the number of practitioners. In Poland, during the first period of the pandemic, there was a record number of business suspensions. While no detailed statistics are available for the real estate valuation industry, nationwide trends indicate that individual entrepreneurs suspended their businesses a total of nearly 300,000 times in 2020. Only in March 2020 did as many as 48,624 entrepreneurs choose to do so, while a year earlier, only 18,089 entrepreneurs decided to take such a step (CEIDG 2021). It can be assumed that this group included Polish real estate valuers who, like other entrepreneurs, faced difficult decisions regarding their immediate professional prospects, especially since nearly $90 \%$ of Polish real estate valuers are sole proprietors (Małkowska and Uhruska 2018). These are individuals who use their own earnings to cover all business expenses and to pay mandatory taxes and pension obligations. In the event of a difficult or precarious income situation, the suspension of business activity that can help, which can be temporary or at least exempt them from tax obligations and pension contributions, which is certainly an interesting alternative in light of the pandemic restrictions.

In order to assess how the pandemic may have affected the activities of valuers, one should consider two main areas of their activity: the number of valuation orders received and the difficulties occurring in terms of their performance. The number of orders depends on the activity of entities operating in the real estate market and their investment expectations. The most frequently serviced group of clients are the so-called individual clients, but corporate entities, banks, courts, and public administration units are also clients. The least frequent group consists of orders from bailiffs. (Małkowska and Uhruska 2019). The most common purpose of valuation carried out by Polish valuers is 
to secure mortgage loans, market sale of real estate, or asset distribution. On the other hand, valuations for the purpose of settlements with public administration bodies (e.g., expropriation of real estate, sale of public property, and administration fees) are quite rare. The orders undertaken relate to a wide variety of real estate. The most valued real estate is undeveloped land. A popular subject of valuation is also land developed with residential buildings and residential premises. The least valued types of real estate are agricultural land and forests.

In 2020, the property market went through some significant changes in the operation of its segments (Freeman 2020; Marona and Tomal 2020; Parker 2020; Voigtländer 2020; Yoruk 2020; Ipsen et al. 2021; Nanda et al. 2021). Generally speaking, it can be said that as a result of the restrictions imposed, as well as in the face of uncertainty, many players reduced their activity to the minimum necessary, which may have reduced the number of valuations ordered. However, the difficult situation in the real estate market may paradoxically have had a positive effect on the number of valuations ordered for the purposes of recording property values, renegotiating financial terms, or for the purposes of settling mutual claims and potential litigation. Demand for property valuation services may increase, but not immediately. Providing property valuations will be necessary for evidentiary purposes in pending loan, business, and court proceedings, which are more likely to be initiated at a later date (i.e., when the pandemic situation is more stable). In the short term, on the other hand, it can be expected that a pandemic is unlikely to provide property valuers with a greater volume of valuation orders. Furthermore, in the face of a pandemic, valuers will experience similar difficulties and constraints to other parallel market players.

In terms of difficulties in performing the orders taken on, valuers in 2020 were faced with a number of problems. The most important of these was the limited access to public institutions and offices that hold sets of property information and transactional data from the market. Under normal circumstances (i.e., pre-pandemic), valuers rely on a variety of sources of property information which are necessary to properly perform the valuation and obtain a reliable result. These are data allowing verification of the legal, technical, and planning status of the property, as well as transactional data of comparable properties which form the basis for determining the property value. Typically, these are data the valuers receive at the office in the formal form of extracts and documents. During the lockdown, offices were not accepting any applicants. There was no possibility to obtain valuation data in person (Horvat et al. 2021). This was possible only remotely by ordering data over the phone or via the internet, which instead of one day took up to several weeks, significantly delaying the execution of orders.

There were attempts to solve some difficulties at the government level, and so on 16 April 2020, the Ministry of Economic Development, Labour and Technology issued recommendations for valuers on how to value property under coronavirus outbreak conditions (Ministry of Economic Development, Labour and Technology 2020), which allowed the use of extraordinary and simplified valuation procedures. The rather controversial facilitation was to allow valuation without a site visit to the property, which until now had been considered as improper diligence in valuation. It also allowed the use of copies and scans instead of original documents in the valuation process. According to these recommendations, all special conditions of the real estate valuation, limitations of access to information, as well as the possible difficulties of inspection of the property should be discussed with the client and clearly described in the valuation report.

At this point, it is worth mentioning the positive changes that have occurred in the publication of real estate data on the internet and the updating of many information platforms. The pandemic has greatly accelerated the publication of various data in electronic resources, and the existing remote solutions have been improved. New opportunities have arisen for valuers in terms of access to remote information about the property market. As a result of the implementation of electronic procedures in public offices and market institutions (Horvat et al. 2021), valuers were able to view sales transactions as well as use the property data available on public institutions' websites. Furthermore, the pandemic 
has revolutionized education services, transferring them from the traditional form to remote teaching via different virtual conference platforms. The professional organizations unsuccessfully tried to get the legal obligation of continuing education abolished during the pandemic (Ciodyk 2020), so despite the epidemic difficulties, Polish valuers still had to fulfill their obligations. Facing pandemic restrictions, professional organizations began providing distance training by offering participants free access to various video platforms. It can be expected that remote work solutions used by real estate valuers will be a practical tool used after the end of the pandemic as well.

In the following part of the paper, the results of a survey conducted among Polish property valuers on the impact of a pandemic on their professional activities are presented.

\section{Data and Methods}

Our research focused on property valuation services provided by licensed valuers. They are information intermediaries supporting decision makers in the real estate market, in the public real estate management, in legal proceedings, as well as in the financial and banking sectors. The continuity of the valuation business depends on orders from individuals, enterprises, institutions, and public entities, which in turn are a function of the activities of the real estate market, the financial sector, and the economy. Thus, in our research, we aimed to find out to what extent the professional activities of valuers were affected by COVID-19. In particular, our objective was to identify the difficulties involved in carrying out the core tasks of property valuation. We also wanted to find out how valuers perceived the pandemic situation and whether COVID-19 was affecting their business outcomes.

In order to fulfill the purpose of the research and answer the questions posed above, we conducted a survey among real estate valuers who were members of professional associations across Poland. The surveys were conducted in early September 2020 and covered the so-called first pandemic period in Poland. A strict lockdown period was declared in Poland on 11 March 2020. Since then, restrictions were tightened several times, with a slow loosening beginning in May. The summer months passed quietly, and despite small increases in the number of cases and expert predictions of another outbreak, there was a sense of calm and hope that the crisis of isolation and social restrictions was over after all. This was a good time to conduct research, as it was possible to obtain a retrospective assessment of the period investigated.

To conduct our survey, we used the computer-assisted web interviewing (CAWI) technique, which was the most available option under the COVID-19 conditions. The questions were closed-ended, where respondents expressed their opinions using a 5-point Likert scale. These included, among other things, the difficulties associated with the work of a valuer, the impact of the COVID-19 pandemic on the number of assignments and valuation income, and the use and learning of new technological tools. In general, the questions presented could be divided into four main issues:

1. Subjective perception of the pandemic situation and related issues (statements: $S_{1} ; S_{9}$; and $\left.S_{10}\right)$;

2. Difficulties in performing valuation activities (statements: $S_{2} ; S_{3}$; and $S_{4}$ );

3. Business outcomes (statements: $S_{5}$ and $S_{6}$ );

4. Technological adaptation (statements: $S_{7}$ and $S_{8}$ ).

The survey question on the impact of the COVID-19 pandemic was stated as follows: Express your attitude to the following statements (considering the period of March-August 2020) by ticking one of the following answers according to the scale: 1-strongly disagree; 2 disagree, 3-no opinion, 4-agree, 5-strongly agree:

$>\quad$ The epidemic threat is an additional source of stress for me in my professional work $\left(S_{1}\right)$.

$>\quad$ It is difficult to access valid market data $\left(S_{2}\right)$.

$>\quad$ Access to institutions supporting the valuation process (county offices, municipal offices, etc.) is limited $\left(S_{3}\right)$.

$>$ Local inspection of the property is more complicated $\left(S_{4}\right)$. 
$>\quad$ The number of new orders has decreased $\left(S_{5}\right)$.

$>\quad$ My income has decreased $\left(S_{6}\right)$.

$>\quad$ I make wider use of existing high-tech tools $\left(S_{7}\right)$.

$>\quad$ I am learning the new tools of modern technology $\left(S_{8}\right)$.

> After the "lockdown" period (i.e., from June 2020), the situation in the valuation services market returned to the pre-pandemic state $\left(S_{9}\right)$.

$>\quad$ The existing recommendations of the Ministry for real estate valuers during a coronavirus pandemic are sufficient $\left(S_{10}\right)$.

The analysis of the responses collected was of a quantitative type.

The survey form was sent to 3438 individuals, who represented roughly half of the total number of individuals holding state licenses to practice real estate valuation. A total of 114 responses were received, of which, after the removal of deficiencies, 107 fully completed survey forms were left for further analysis. The characteristics of the research sample are shown in Table 1.

Table 1. Description of the research sample.

\begin{tabular}{cccc}
\hline Feature & Number & $\begin{array}{c}\text { Percentage of } \\
\text { Respondents (\%) }\end{array}$ & $\begin{array}{c}\text { Cumulative } \\
\text { Percentage (\%) }\end{array}$ \\
\hline Gender & 107 respondents & & \\
Men & 63 & $58.88 \%$ & $58.88 \%$ \\
Women & 44 & $41.12 \%$ & $100.00 \%$ \\
Seniority & $2-35$ years & & \\
\hline Up to 5 years & 15 & $14.02 \%$ & $14.02 \%$ \\
6-10 years & 24 & $22.42 \%$ & $36.44 \%$ \\
11-20 years & 34 & $31.78 \%$ & $68.22 \%$ \\
Over 20 years & 34 & $31.78 \%$ & $100.00 \%$ \\
\hline Number of valuations per & $1-30$ valuation & & \\
month & reports per month & & \\
\hline Up to 5 valuations & 58 & $54.20 \%$ & $78.50 \%$ \\
6-10 valuations & 26 & $24.30 \%$ & $100 \%$ \\
Above 10 valuations & 23 & $21.50 \%$ & \\
\hline
\end{tabular}

The gender structure of the respondents broadly corresponded to that of the general population of real estate valuers in Poland. In 2020, among the 7591 licensed valuers, $46 \%$ were women and $54 \%$ were men (Dudek 2020). The majority of the respondents were those with relatively long work experience (i.e., over 10 years). Conversely, when considering the scale of the business and the average number of valuations carried out, over half of the respondents were those making only up to five valuations per month. These two dominant groups (long seniority and low number of valuations performed per month) in the sample may seem surprisingly contradictory, as one would commonly expect the number of valuations performed to be correlated with seniority; the longer the seniority, the more developed and established the valuer's relationships with clients and the greater the number of assignments performed by the valuer. While in principle this line of thinking is not incorrect, the specific nature of the valuation profession leads to diverse forms of running business. Our survey sample reflected this, showing a low and negative correlation between seniority and the number of valuations performed per month (Figure 1).

The absence of the relationship described above is easily explained. This is because a significant percentage of the licensed valuers provided valuation services as a side job combined with other professional activity or operated on a small scale as sole traders (Małkowska and Uhruska 2018). 


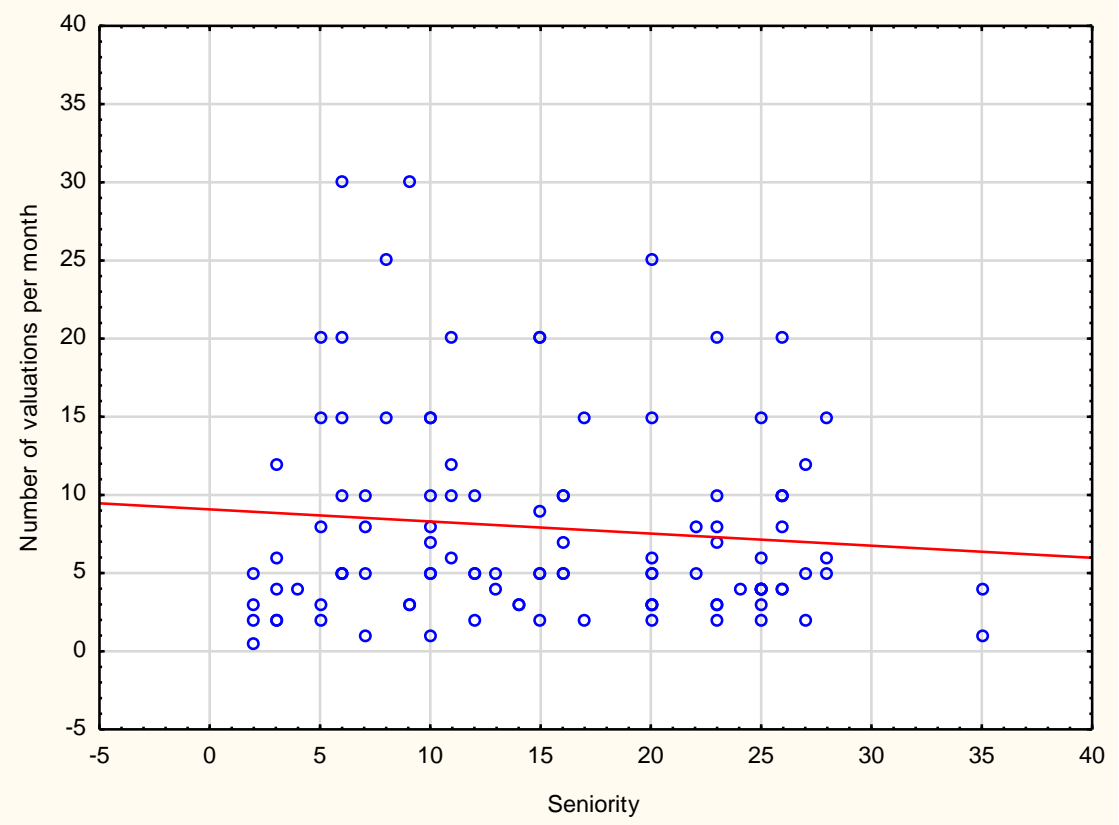

Figure 1. Correlation between seniority and the number of valuations produced.

\section{Research Findings and Discussion}

The results of the survey show that the respondents experienced pandemic difficulties primarily in their professional tasks of carrying out property valuations. They also noticed a negative impact on their business results. The statements' content and the results of the responses followed by their descriptive statistics are presented in Table 2.

Table 2. Descriptive statistics of respondents' answers to survey questions.

\begin{tabular}{|c|c|c|c|c|c|c|c|c|c|c|c|c|c|}
\hline \multirow{2}{*}{ Ref. } & \multirow{2}{*}{ Statements Evaluated } & \multirow{2}{*}{$\begin{array}{l}\text { Obs. } \\
\text { No }\end{array}$} & \multicolumn{5}{|c|}{ Freq. of Responses (\%) } & \multirow{2}{*}{ Sum } & \multirow{2}{*}{ Mean } & \multirow{2}{*}{ Median } & \multirow{2}{*}{ Mode } & \multirow{2}{*}{$\begin{array}{l}\text { Freq. of } \\
\text { Mode }\end{array}$} & \multirow{2}{*}{$\begin{array}{l}\text { Std. } \\
\text { Dev }\end{array}$} \\
\hline & & & $1 *$ & $2 *$ & $3 *$ & $4 *$ & $5 *$ & & & & & & \\
\hline $\mathrm{S}_{1}$ & $\begin{array}{l}\text { The epidemic threat is an } \\
\text { additional source of stress for } \\
\text { me in my professional work }\end{array}$ & 107 & 14.02 & 28.04 & 14.95 & 30.84 & 12.15 & 320 & 2.99 & 3 & 4 & 33 & 1.28 \\
\hline $\mathrm{S}_{2}$ & $\begin{array}{l}\text { It is difficult to access valid } \\
\text { market data }\end{array}$ & 107 & 1.87 & 19.63 & 4.67 & 30.84 & 42.99 & 421 & 3.93 & 4 & 5 & 46 & 1.20 \\
\hline $\mathrm{S}_{3}$ & $\begin{array}{l}\text { Access to institutions } \\
\text { supporting the valuation } \\
\text { process (county offices, } \\
\text { municipal offices, etc.) } \\
\text { is limited }\end{array}$ & 107 & 0.93 & 10.28 & 0.93 & 34.58 & 53.27 & 459 & 4.29 & 5 & 5 & 57 & 0.98 \\
\hline $\mathrm{S}_{4}$ & $\begin{array}{l}\text { Local inspection of the } \\
\text { property is more complicated }\end{array}$ & 107 & 5.61 & 37.38 & 16.82 & 26.17 & 14.02 & 327 & 3.06 & 3 & 2 & 40 & 1.20 \\
\hline $\mathrm{S}_{5}$ & $\begin{array}{c}\text { The number of new orders } \\
\text { has decreased }\end{array}$ & 107 & 6.54 & 21.50 & 19.63 & 29.91 & 22.43 & 364 & 3.40 & 4 & 4 & 32 & 1.24 \\
\hline $\mathrm{S}_{6}$ & My income has decreased & 107 & 9.35 & 18.69 & 14.95 & 31.78 & 25.23 & 369 & 3.45 & 4 & 4 & 34 & 1.30 \\
\hline $\mathrm{S}_{7}$ & $\begin{array}{l}\text { I make wider use of existing } \\
\text { high-tech tools }\end{array}$ & 107 & 4.67 & 5.61 & 25.23 & 41.12 & 23.36 & 399 & 3.73 & 4 & 4 & 44 & 1.03 \\
\hline $\mathrm{S}_{8}$ & $\begin{array}{l}\text { I am learning the new tools of } \\
\text { modern technology }\end{array}$ & 107 & 3.74 & 13.08 & 26.17 & 39.25 & 17.76 & 379 & 3.54 & 4 & 4 & 42 & 1.05 \\
\hline $\mathrm{S}_{9}$ & $\begin{array}{l}\text { After the "lockdown" period } \\
\text { (i.e., from June 2020), the } \\
\text { situation in the valuation } \\
\text { services market returned to the } \\
\text { pre-pandemic state }\end{array}$ & 107 & 14.95 & 33.64 & 31.78 & 14.95 & 4.67 & 279 & 2.61 & 3 & 2 & 36 & 1.06 \\
\hline $\mathrm{S}_{10}$ & $\begin{array}{c}\text { The existing recommendations } \\
\text { of the Ministry for real estate } \\
\text { valuers during a coronavirus } \\
\text { pandemic are sufficient }\end{array}$ & 107 & 18.69 & 24.30 & 36.45 & 16.82 & 3.74 & 281 & 2.63 & 3 & 3 & 39 & 1.09 \\
\hline
\end{tabular}

* 1—strongly disagree; 2-disagree; 3-hard to say; 4-agree; and 5-strongly agree. 
The most serious problem for valuers during the first COVID-19 period appeared to be limited access to public institutions that supported the valuation process. Respondents' opinions in this regard were the least divergent compared with other statements. Public institutions in Poland play a significant role in the valuation process, as they maintain records and registers of real estate, from which information and documents are needed for valuation reports. In the COVID-19 pandemic, along with the lockdown, a remote work recommendation was introduced for all positions, both in the private and public sectors. As a result, public offices have reduced direct contact with clients by gradually shifting the delivery of administrative services to the internet. The key problem, however, has proven to be the relatively low level of technological readiness for remote working of most institutions and businesses. Comparative studies conducted before 2020 covering the European Union countries show that Poland ranked low in terms of the level of digitization of society, companies, and public administration (Ardielli and Halásková 2015; Małkowska et al. 2021).

The second most important problem for real estate valuers was limited access to current market data. This is largely linked to the public institutions that collect purchase and sale deeds for real estate and provide information from these acts to experts. Nevertheless, it should be emphasized that the availability of up-to-date transactional price data in Poland was imperfect already before the pandemic (Kucharska-Stasiak 2009). This was due to the fact that the procedure for registering notarial acts and making them available was completed with a significant delay in relation to the date of the transaction. This became even more problematic during the pandemic, when direct access to offices was restricted. Looking at the descriptive statistics of the respondents' answers, a slightly greater variation in responses was apparent here. This was probably due to the diverse level of availability of transactional data to valuers. If a given valuer benefits on a daily basis from access to transaction price databases created and maintained by private bodies on the basis of data from public institutions, his or her opinion may differ from those valuers who only use registers maintained by public administration. In the former case, access to data is easier and quicker as a result of teamwork and joint maintenance of the transaction price database. A second reason for the variation in respondents' opinions was likely the short period of experience with COVID-19 at the time the surveys were conducted, which might not yet have had too much influence on their work.

Our study also verified some positive effects induced by COVID-19. These were mainly digitalization and the wider use of modern technology tools by valuers. So far, the real estate sector in Poland has been relatively less technologically advanced compared with other UE countries (Małkowska 2020). Pandemic necessity has accelerated processes in those areas which, due to their specific natures, have not previously made extensive use of new technological possibilities. The structure of the responses by gender showed some differences when it came to the propensity to use new technologies (Figure 2).

COVID-19 and its restrictions also had an impact on the number of new assignments and income levels. These effects were reported by around half of the respondents. The variation in respondents' opinions on this point may have depended on the previous client structure served and any specialization in valuation (e.g., frequent valuations for public bodies).

When it came to respondents' subjective feelings about their assessment of the current situation, more than $42 \%$ of the respondents viewed the pandemic as an additional source of work stress. Quite peculiarly, gender seemed to make some difference in feeling stressed or, more likely, in admitting to being stressed. As can be seen from the distribution of responses in Figure 3, female valuers were most likely to say that the epidemiological threat was a source of additional stress for them at work. In the case of men, the opposite opinion was expressed more often. 


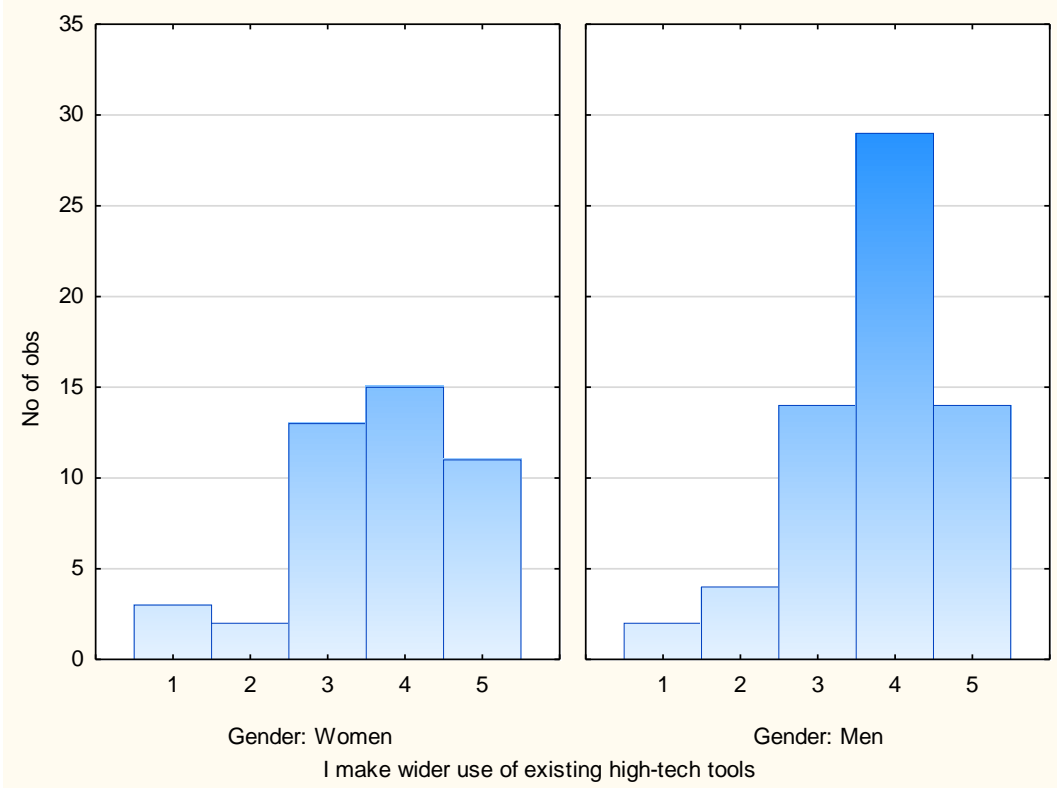

Figure 2. Distribution of respondents' answers about using high-tech tools.

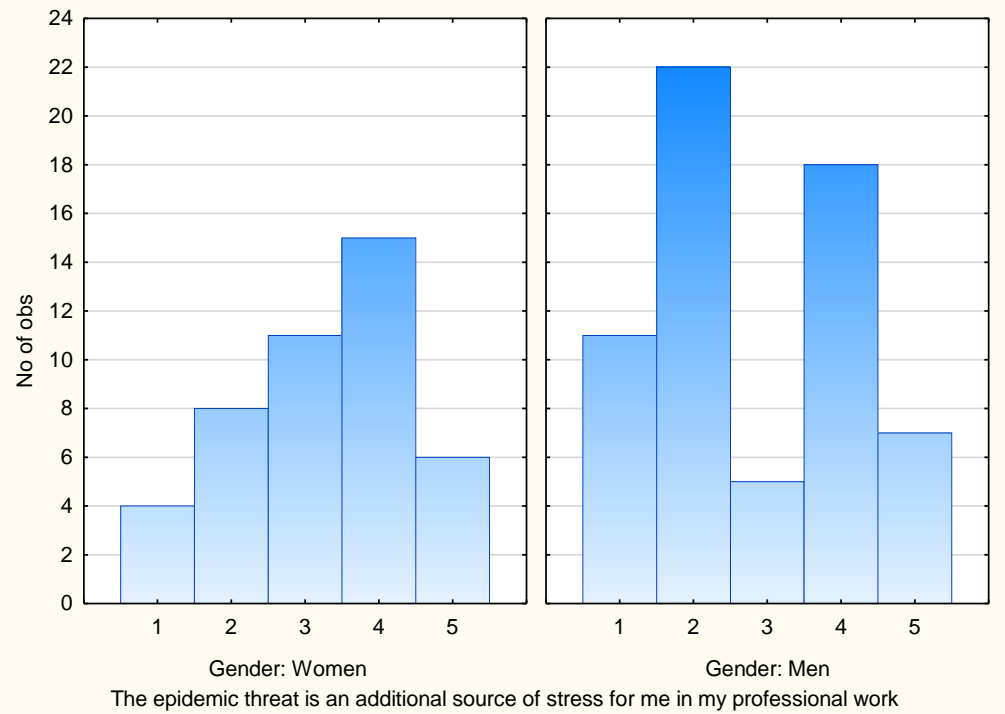

Figure 3. Distribution of respondents' answers about experiencing stress due to the COVID-19 pandemic (by gender).

The assessment of stability in the valuation services market after the first lockdown in June-August 2020 was rather negative, as $48 \%$ of the respondents felt that despite the calming of the outbreak and the reduction of restrictions over the summer, the working conditions for valuers had not returned to those before the pandemic.

The respondents appeared to be quite divided in their assessment of two issues: the difficulty of conducting property inspections and formal support from authorities. About the same number of valuers found it more difficult to conduct property inspections as those expressing the opposite view. The formal support provided to property valuers by the Ministry in the form of recommendations for valuation during a pandemic was rated slightly worse. The majority of valuers believed that these recommendations were not sufficient.

When comparing the responses of the valuers in the four groups distinguished by length of experience (Figure 4), it can be seen that for most statements, the mean scores were 
not significantly different. This was also confirmed by the results of the Kruskal-Wallis test.

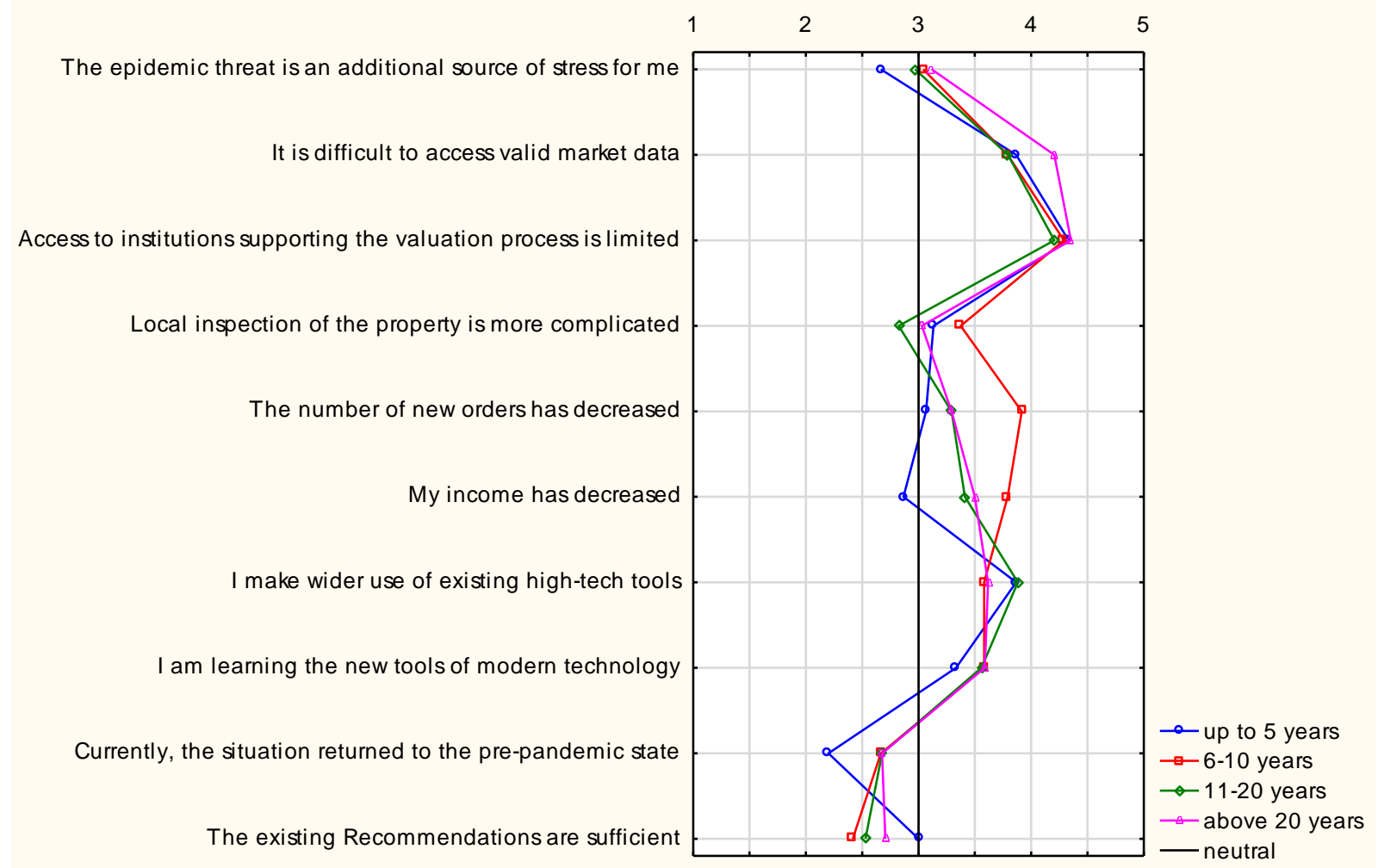

Figure 4. The means of the respondents' answers in groups by seniority.

The only discrepancies in the mean responses visible in Figure 4 are between two groups-those with the shortest length in valuation service (up to 5 years) and those working between 5 and 10 years in the profession-and relate to a decline in the number of assignments and income. These discrepancies can be explained by the fact that valuers with little seniority tend to undertake standard valuations, which do not require complex market data or detailed analysis. They were not affected by the decline in the number of orders as such valuations continued to be performed in the market, keeping their incomes stable. The situation was different in the case of more experienced people, performing more difficult valuations. Such orders are usually less frequent but more lucrative. Those valuers were more likely to be affected by the lack of orders and the fall in their incomes.

Analysis of the respondents' answers by the scale of activity did not reveal significant differences in the average answers for the groups (Figure 5).

This suggests that neither professional experience nor established market position differentiate valuers in assessing the impact of COVID-19 on their business. The reasons for differences in perceptions of the pandemic situation are more complex and likely depend on the individual circumstances in which a particular expert operates. 


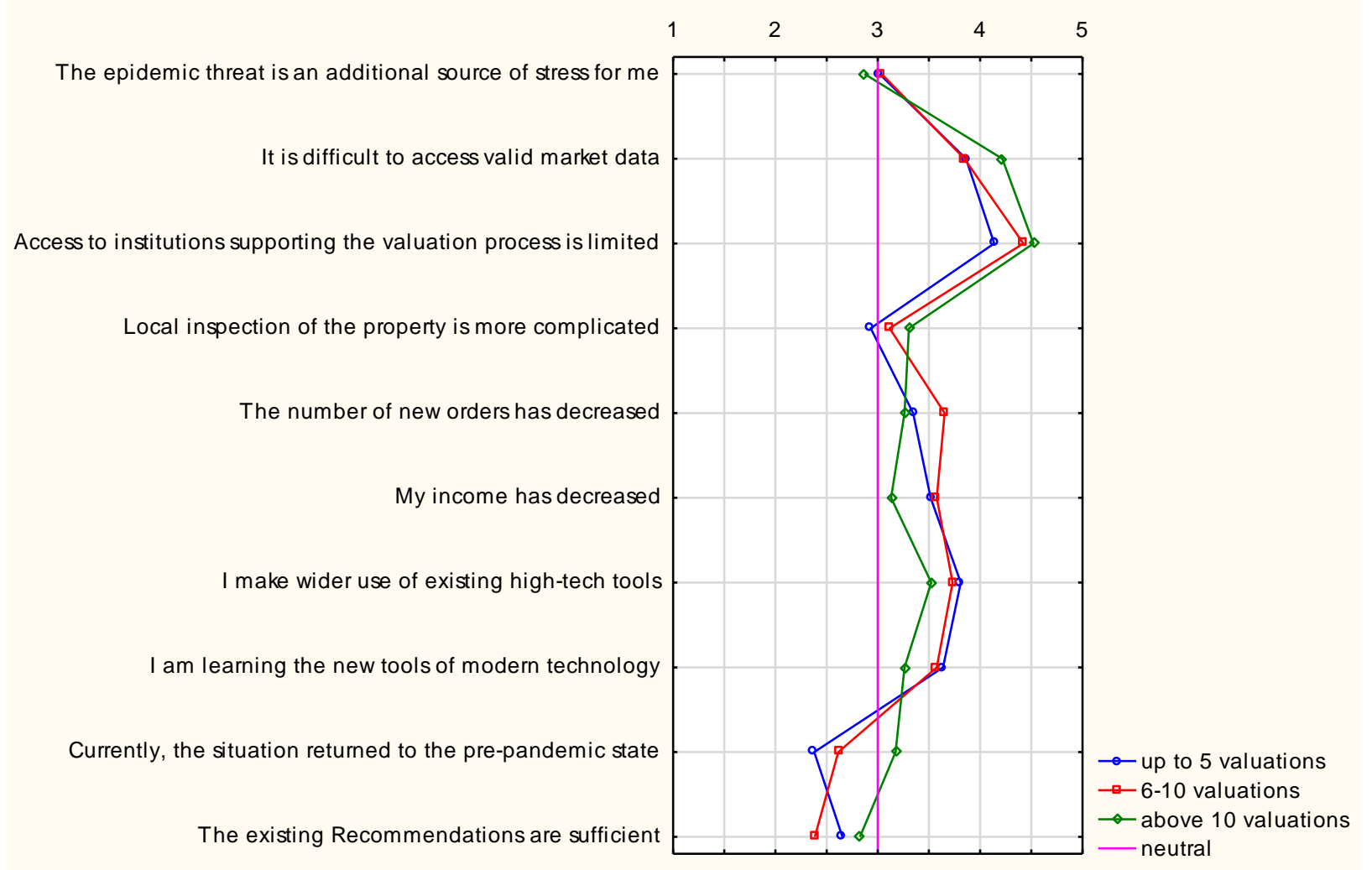

Figure 5. The means of respondents' answers in groups by number of valuations per month.

\section{Conclusions}

The COVID-19 pandemic has left its mark on all areas of economic life. Global restrictions, widespread lockdown, and social distancing forced millions of people to scale back their activities with enormous economic consequences. The pace and direction of these changes show the unprecedented nature of the entire process. The impact of the pandemic could be felt in various industries (He et al. 2020), which also had a broad impact on the real estate market and the entities operating in it.

Valuers, like others in the real estate industry during the first period of the pandemic, encountered problems in limiting their activities as a result of the widely imposed lockdown and restriction of activity by potential principals. After a month of strict lockdown and a freeze on all activity, real estate entities quickly returned to their activities, although a full return continued to be difficult. The difficulties were mainly due to demand constraints, conditioned by investors' fears and uncertainties, tenants' increased caution and changing preferences, reduced creditworthiness, and limited mortgage lending. At the same time, public institutions dealing with real estate transactions and supporting market turnover, out of concern for the health of their employees, introduced remote or rotational service for investors, which made cooperation with these entities and access to necessary documents and market data much more difficult.

The activities of real estate valuers have also faced a number of impediments and constraints. As can be seen from the surveys carried out on the activity of valuers in the first period of the pandemic (i.e., from March to September 2020), valuers confirmed the existence of a number of problems. First of all, they clearly pointed to the difficulty in contacting public institutions and obtaining the documents necessary for valuations. They also confirmed a decline in the volume of assignments and a drop in income, although not all of them were so pessimistic, with the less experienced members of the profession expressing greater optimism. Moreover, valuers did not express positive views on the extent of government support. The facilitation of professional activities proposed by the 
relevant ministry was considered insufficient in consideration of the real market problems. Pessimistic assessments of the professional community were expressed about the evaluation of the professional situation after the end of the first lockdown. They assessed that after the end of the lockdown, the situation for the market of valuation services did not return to the pre-pandemic state. There was also a positive aspect of the pandemic; namely, valuers confirmed that due to the necessity of obtaining market data remotely, they learned to use new technological tools and implemented them in their professional practices.

The research carried out on the impact of the COVID-19 pandemic on the business of Polish property valuers was the first to be conducted in this specialized, narrow professional group. This research was limited only to the first wave of the pandemic, which seems to have been most noticeable in the conduct of valuers' own business. In the later period, despite the following much larger increases in the number of daily coronavirus cases, none of the industries in the economy suffered any more of a freeze than in the first period. Our study certainly does not present a complete picture of the valuation activity during the pandemic era, as it is limited only to the first few months of this new phenomenon. Further research may continue the theme of assessing the property valuers' professional activity during further periods of the pandemic, which would complement the present study. The issue of changes in the scope of activity may be of particular interest. Special attention could be given to the assessment of the range of valuations performed (i.e., whether the structure of clients served and the types of valuation provided for them changed as a result of the ongoing pandemic and changing market conditions), which could provide a backdrop to further discussion on the future of the valuation profession.

Author Contributions: Conceptualization, A.M. and M.U.; methodology, A.M.; formal analysis, A.M. an M.U.; investigation, A.M. and M.U.; writing—original draft preparation, A.M. and M.U.; writing-review and editing, M.U. Both authors have read and agreed to the published version of the manuscript.

Funding: The publication was financed from a subsidy granted to Cracow University of Economics.

Data Availability Statement: The survey data presented in this study are available upon request from the corresponding author.

Conflicts of Interest: The authors declare no conflict of interest.

\section{References}

Abay, Kibrom A., Kibrom Tafere, and Andinet Woldemichael. 2020. Winners and Losers from COVID-19: Global Evidence from Google Search; World Bank Policy Research Working Paper 9268; Washington: World Bank. Available online: https://openknowledge. worldbank.org/handle/10986/33852 (accessed on 8 June 2021).

Abed, Salma S. 2021. A literature review exploring the role of technology in business survival during the Covid-19 lockdowns. International Journal of Organizational Analysis. [CrossRef]

Ardielli, Eva, and Martina Halásková. 2015. Assessment of E-government in EU Countries. Scientific Papers of the University of Pardubice. Series D, Faculty of Economics and Administration 22: 4-16.

Bartke, Stephan, and Reimund Schwarze. 2015. The Economic Role of Valuers in Real Property Markets. UFZ Discussion Papers Department of Economics 13/2015. Leipzig: Helmholtz-Zentrum für Umweltforschung-UFZ.

CEIDG. 2021. Centralna Ewidencja i Informacja o Działalności Gospodarczej (Central Register and Information on Business Activity), Data Provider: The Ministry of Economic Development, Labour and Technolgy. Available online: https://dane.gov.pl/pl/ dataset/745,informacja-o-liczbie-wnioskow-zozonych-w-ceidg (accessed on 7 June 2021).

Central Register of Property Valuers. 2021. Ministry of Economic Development, Labour and Technology. Available online: https: / / rejestresrm.mrpit.gov.pl/ (accessed on 5 June 2021).

Ciodyk, Tomasz. 2020. President of Polish Federal of Valuers Association, Letter to the Ministry of Development. April 17. Available online: https:/ / pfsrm.pl/aktualnosci/item/595-doskonalenie-kwalifikacji-zawodowych-w-2020-r-wniosek-pfsrm-do-ministra (accessed on 10 June 2021).

Coronavirus: Information and Recommendations. 2020. Website of the Republic of Poland. Available online: https:/ /www.gov.pl/ web / coronavirus / current-rules-and-restrictions (accessed on 5 June 2021).

Cymerman, Ryszard. 2021. Speech as a Chairman of the State Qualification Commission during the Plenary Meeting of the State Qualification Commission on May 12, 2021. Warsaw: Ministry of Economic Development, Labour and Technology. 
Dudek, Michał. 2020. Real estate valuers in Poland-Spatial Report 2020. Available online: https://iccs.pl/blog/2020/06/24 /rzeczoznawcy-majatkowi-w-polsce-raport-przestrzenny-2020-r/ (accessed on 5 June 2021).

Fabeil, Noor Fzlinda, Khairul Hanim Pazim, and Juliana Langgat. 2020. The Impact of COVID-19 Pandemic Crisis on Micro-Enterprises: Entrepreneurs' Perspective on Business Continuity and Recovery Strategy. Journal of Economics and Business 3: 837-44. [CrossRef]

Fairlie, Robert, and Frank M. Fossen. 2021. The early impacts of the COVID-19 pandemic on business sales. Small Business Economics, 1-12. [CrossRef]

Freeman, Elam. 2020. Impacts of the COVID-19 Pandemic: How Retail, Office and Industrial May Be Affected by Changes in Human Behavior. Real Estate Issues 44: 1-4.

Gross, Marta. 2021. Real estate management in COVID-19 pandemic conditions. Paper presented at Conference Presentation, International Scientific-Methodical Conference "Baltic Surveying'21", Jelgava, Latvia, May 6.

Hasanat, Mohammad Waliul, Ashikul Hoque, Farzana Afrin Shikha, Mashrekha Anwar, Abu Bakar Abdul Hamid, and Huam Hon Tat. 2020. The Impact of Coronavirus (Covid-19) on E-Business in Malaysia. Asian Journal of Multidisciplinary Studies 3: 85-90.

He, Pinglin, Hanlu Niu, Zhe Sun, and Tao Li. 2020. Accounting Index of COVID-19 Impact on Chinese Industries: A Case Study Using Big Data Portrait Analysis. Emerging Markets Finance and Trade 56: 2332-49. [CrossRef]

Horvat, Matej, Wojciech Piątek, Lukáš Potěšil, and Krisztina F. Rozsnyai. 2021. Public Administration's Adaptation to COVID-19 Pandemic-Czech, Hungarian, Polish and Slovak Experience. Central European Public Administration Review 19: 133-58.

International Valuation Standards. 2020. International Valuation Standards Council. Available online: www.ivsc.org (accessed on 11 June 2021).

Ipsen, Christine, Marc van Veldhoven, Kathrin Kirchner, and John P. Hansen. 2021. Six Key Advantages and Disadvantages of Working from Home in Europe during COVID-19. International Journal of Environmental Research and Public Health 18: 1826. [CrossRef]

Konowalczuk, Jan. 2017. The Problem of Reflecting the Market in the Legal Principles of Real Estate Valuation in Poland. How to eliminate the "Legal Footprint"? Real Estate Management and Valuation 25: 44-57. [CrossRef]

Koszel, Maciej. 2021. The COVID-19 Pandemic and the Professional Situation on the Real Estate Market in Poland. Paper presented at International Scientific Conference Hradec Economic Days 2021, Hradec Králové, Czech Republic, March 25-26; pp. 412-25. [CrossRef]

Kucharska-Stasiak, Ewa. 2009. Uncertainty of Valuation in Expropriation Processes-The Case of Poland. Nordic Journal of Surveying and Real Estate Research 3. Available online: https://journal.fi/njs/article/view/2452 (accessed on 3 June 2021).

Majumder, Soumi, and Debasish Biswas. 2021. COVID-19: Impact on quality of work life in real estate sector. Quality $\mathcal{E}$ Quantity. [CrossRef]

Małkowska, Agnieszka. 2020. How Technology Impact the Real Estate Business-Comparative Analysis of European Union Countries. World of Real Estate Journal 2: 58-81. [CrossRef]

Małkowska, Agnieszka, and Małgorzata Uhruska. 2018. Doing Business in Property Valuation-Survey Results. World of Real Estate Journal 106: 27-36.

Małkowska, Agnieszka, and Małgorzata Uhruska. 2019. Towards specialization or extension? Searching for valuation services models using cluster analysis. Real Estate Management and Valuation 27: 27-38. [CrossRef]

Małkowska, Agnieszka, Maria Urbaniec, and Małgorzata Kosała. 2021. The impact of digital transformation on European countries: Insights from a comparative analysis. Equilibrium. Quarterly Journal of Economics and Economic Policy 16: 325-55. [CrossRef]

Marona, Bartłomiej, and Mateusz Tomal. 2020. The COVID-19 pandemic impact upon housing brokers' workflow and their clients' attitude: Real estate market in Krakow. Entrepreneurial Business and Economics Review 8: 221-32. [CrossRef]

Ministry of Economic Development, Labour and Technology. 2020. Recommendations for Valuers on How to Value Property under Coronavirus Outbreak Conditions. Available online: https:/ /www.gov.pl/web/rozwoj-praca-technologia/rekomendacje-dlarzeczoznawcow-majatkowych (accessed on 11 June 2021).

Nanda, Anupam, Yishuang Xu, and Fangchen Zhang. 2021. How would the COVID-19 pandemic reshape retail real estate and high streets through acceleration of E-commerce and digitalization? Journal of Urban Management 10: 110-24. [CrossRef]

National Valuation Standards. 2021. Polish Federation of Valuers Associations. Available online: https://pfsrm.pl/aktualnosci/item/ 14-standardy-do-pobrania (accessed on 11 June 2021).

Parker, Lee D. 2020. The COVID-19 office in transition: Cost, efficiency and the social responsibility business case. Accounting, Auditing \& Accountability Journal 33: 1943-67. [CrossRef]

Priyono, Anjar, Abdul Moin, and Vera Nur Aini Oktaviani Putri. 2020. Identifying Digital Transformation Paths in the Business Model of SMEs during the COVID-19 Pandemic. Journal of Open Innovation: Technology, Market, and Complexity 26: 104. [CrossRef]

Real Estate Management Act. 1997. August 21. (Dz. U. 1997 Nr 115 poz. 741, Amended). Available online: https://isap.sejm.gov.pl/ isap.nsf/download.xsp/WDU19971150741/U/D19970741Lj.pdf (accessed on 15 June 2021).

Regulation on Real Estate Valuation and Making a Valuation Report. 2004. September 21 (Dz.U. 2004 poz. 2109, amended). Available online: https: / isap.sejm.gov.pl/isap.nsf/download.xsp/WDU20042072109/O/D20042109.pdf (accessed on 15 June 2021).

Savić, Dobrica. 2020. COVID-19 and Work from Home: Digital Transformation of the Workforce. Grey Journal (TGJ) 16: 101-4.

Seetharaman, Priya. 2020. Business models shifts: Impact of Covid-19. International Journal of Information Management 54: 102173. [CrossRef]

Shen, Huayu, Mengyao Fu, Hongyu Pan, Zhongfu Yu, and Yongquan Chen. 2020. The Impact of the COVID-19 Pandemic on Firm Performance. Emerging Markets Finance and Trade 56: 2213-30. [CrossRef] 
Sheth, Jagdish. 2020. Business of business is more than business: Managing during the Covid crisis. Industrial Marketing Management 88: 261-64. [CrossRef]

Slade, Margaret E. 2020. Many Losers and A Few Winners: The Impact of COVID-19 on Canadian Industries and Regions. Available online: https://econ2017.sites.olt.ubc.ca/files/2020/09/pdf_paper_slade-e-margaret_ImpactOfCOVID19OnCanadianIndustriesAndRegions.pdf (accessed on 8 June 2021).

Sokol, Martin, and Leonardo Pataccini. 2020. Winners and losers in coronavirus times: Financialisation, financial chains and emerging economic geographies of the COVID-19 pandemic. Tijdschrift voor Economische en Sociale Geografie 111: 401-15. [CrossRef] [PubMed]

Tkach, Dimitriv V., and Konstantin Kurpayanidi. 2020. Some questions about the impact of the COVID-19 pandemic on the development of business entities. International Scientific Journal, Theoretical \& Applied Science 11: 1-4. [CrossRef]

Voigtländer, Michael. 2020. A Perfect Storm for European Office Markets? Potential Price Effects of the Covid-19 Pandemic. IW-Report No. 28/2020. Köln, Germany: Institut der Deutschen Wirtschaft.

Yoruk, Baris. 2020. Early Effects of the COVID-19 Pandemic on Housing Market in the United States. Available online: https: / / ssrn.com/abstract=3607265 (accessed on 10 June 2021).

Źróbek, Sabina, and Chris Grzesik. 2013. Modern challenges facing the valuation profession and allied university education in Poland. Real Estate Management and Valuation 21: 14-18. [CrossRef] 